\title{
TERMÉKFEJLESZTÉS ÉS ÜZLETI TELJESÍTMÉNY
}

A szerzó dolgozatában arra keresi a választ egy empirikus felmérésre támaszkodva, hogy a termékfejlesztési tevékenység gyakorlata hogyan hat az új termékek sikerességére és a vállalatok üzleti teljesítményére. ${ }^{1}$

\section{Kulcsszavak: innováció, termékfejlesztés, üzleti eredményesség}

Hosszú évtizedekre visszanyúló nagyszámú kutatás és publikáció eredményei alapozzák meg azokat az ismereteinket, amelyek a sikeres termékfejlesztés tényezóivel és a siker mérésével kapcsolatosak. Cikkünkben egy hazai vállalati minta alapján vizsgáljuk a termékfejlesztési gyakorlat hatását a termékfejlesztések sikerességére és a cégek üzleti eredményességére. Ehhez elôször a vonatkozó széles körú irodalomból áttekintjük azokat a külföldi forrásmúveket, amelyeket e tanulmányban felhasználtunk a termékfejlesztési gyakorlat színvonalának mérését szolgáló változók kialakításához.

\section{A sikeres termékfejlesztési gyakorlat fóbb jellemzői}

Az 1960-as években indultak azok a felmérések, amelyek arra keresték a választ, hogy mitól lesz sikeres egy innováció, illetve milyen jellemzói vannak az innovációban élenjáró vállalatoknak. Kezdetben inkább a termék-, késóbb a vállalati szintû́ kutatások domináltak.

A témakörben úttörónek számító angliai SAPPHO projekt keretében 43 innovációs projektet - amiból 22 vegyipari eljárás, 21 pedig tudományos kutatásban használt múszer volt - vizsgáltak meg. Az azonos piacokra irányuló sikeres és sikertelen fejlesztéseket állították párba, s keresték azokat az okokat, melyek a sikerhez, illetve a kudarchoz vezettek (Rothwell, 1974). A legfontosabb öt tényező, amiben a sikeres innovációk különböztek a sikertelenektől, a következók voltak:

- a fogyasztói igények megértése s az azokhoz való alkalmazkodás,

- figyelem a marketingtevékenységekre, például abban, hogy a legmegfelelőbb felhasználót megtalálják,
- szoros kapcsolat egyetemekkel, kutatóintézetekkel,

- külsố múszaki szakemberek bevonása a fejlesztési munkába,

- a termékfejlesztések felelősei szélesebb hatáskörrel rendelkeztek, a szervezeti hierarchiában magasabb helyet foglaltak el.

Robert Cooper (1980) nevéhez fúződik a hetvenes évek második felében indult, $\mathrm{s}$ a nyolcvanas években is folytatódó NewProd projekt, mely szintén a sikeres és sikertelen fejlesztések jellemzó jegyeit vizsgálta. Fő megállapításuk, hogy a versenytársak termékeivel szemben lényegi előnyöket nyújtó új termékek sikeresek, s egyaránt szükséges a magas színvonalú marketing- és gyártási szakértelem.

Zirger és Maidique (1990) 330 elektronikai iparágból származó új termék fejlesztési folyamatának elemzése alapján három kulcssikertényezőt talált:

- megfelelố kompetencia a marketing-, a K+F/ Engineering- és a termelési funkciókhoz,

- a három funkció szoros együttmúködése,

- a fogyasztókkal való intenzív kommunikáció.

Ezen kívül bizonyos külsố tényezók, mint például a nagy és növekvő piac, vagy a gyenge verseny növeli a fejlesztési projektek sikerének valószínúségét.

Montoya-Weiss és Calantone (1994) több hasonló metodikájú kutatás összegzése alapján az új termékek sikerének vállalati belsố tényezôit a következókben foglalta össze:

- jártasság a múszaki és a marketingtevékenységekben,

- jártasság a termékfejlesztés folyamatának a konkrét múszaki tevékenységeket megelôző szakaszaiban (ötletgyújtés, ötletek szelektálása, termékkoncepció kialakítása és tesztje), 
- a felsố vezetés támogatása,

- a fejlesztés időigénye,

- külsố és belsố kapcsolatok a fejlesztésben részt vevốk között.

A késóbbi kutatások során Cooper és munkatársa, Kleinschmidt, a termékfejlesztési tevékenységet végzô vállalatot tette vizsgálata tárgyává, mivel projekt szinten nem kaphatunk teljes képet a termékfejlesztésrôl (Cooper - Kleinschmidt, 1995). Lehetnek például olyan tényezók, amelyek projektszinten nem vehetốk figyelembe (például a cég innovációs stratégiája), és a vállalati szintú és projektszintú siker sem mindig esik egybe. Így például hiába van a vállalatnak néhány sikeres új fejlesztése, amennyiben a fejlesztési tevékenység eredményességét az új termékekból származó árbevétellel mérjük, s ezek az új termékek relatíve kis súlyt képviselnek a vállalat forgalmában, akkor a vállalat megítélése az új termékek eredményessége vonatkozásában gyengébb lesz. A sikert több dimenzióban mérték, többek között: az új termékekból származó árbevétel aránya, a sikeres új termékek aránya, az új termékek ráfordításainak megtérülése, múszaki sikeresség. A legfontosabb tényezók, amelyek megkülönböztették a legsikeresebb vállalatokat, a következók voltak:

- a vállalat termékfejlesztési teljesítményének legfontosabb tényezóje a magas színvonalú termékfejlesztési folyamat az ötletgyújtéstől a piaci bevezetésig,

- a második legfontosabb tényezó egy világos, a vállalat felé jól kommunikált, új termékstratégia,

- a felsố vezetés támogatása szintén kritikus megkülönböztetô tényezőnek bizonyult (megfelelô anyagi és emberi erôforrások biztosítása, részvétel a kritikus döntések meghozatalában, jó innovációs légkör kialakítása),

- hagyományos piacaikra fókuszáltak,

- keresztfunkcionális teameket hoztak létre.

Mint a szerzók megállapítják, e kutatás legfontosabb eredménye, hogy elsố ízben mutatták ki kvantitatív módon a korábbi hasonló kutatások során már azonosított tényezốk hatását a vállalat termékfejlesztési teljesítményére. Korábbi felmérésekre és tanulmányokra támaszkodva hat dimenzió mentén próbálják meg felvázolni a legjobb gyakorlatot Kenneth és szerzôtársai (2006). Ezek szerint az ilyen cégek termékfejlesztési tevékenységét hosszú távra tekintő stratégiai szemlélet jellemzi, formális és szisztematikus portfóliómenedzsmentet folytatnak, azaz igyekeznek úgy szürni a felmerülő termékkoncepciókat, hogy egyensúlyban legyenek az úttörő és inkrementális jellegú projektek, formalizálják a fejlesztési folyamatot, a fő mérföldköveknél a döntési kritériumok jól meghatározottak, az egész folyamat jól dokumentált, proaktív piackutatást folytatnak, keresztfunkcionális teameket alkalmaznak, standard kritériumrendszert állítanak fel a projektek kiértékelésére.

\section{A termékfejlesztési gyakorlat hatása a termékfejlesztési és az üzleti teljesítményre}

Elemzésünket a Budapesti Corvinus Egyetem Versenyképesség Kutató Központja által indított „Versenyben a világgal 2004-2006" kutatás adatbázisát felhasználva végeztük el. A minta 300 vállalatának felét adó feldolgozóipari cégeket vontuk be a vizsgálatba, ezen belül is azt a 109 vállalatot, amelyek 2001-2003 között bevezettek új terméket, tehát biztosan végeztek fejlesztési tevékenységet. Az eredeti minta nem reprezentativ a magyar gazdaság egészére nézve, felülreprezentáltak a közepes méretú vállalatok, a hazai tulajdonúak s nem tartalmaz tíz fónél kisebb, úgynevezett mikrovállalkozásokat (Lesi, 2005).

Először a rendelkezésünkre álló kérdőív alapján öszszeállítottuk a változók egy olyan csoportját, amely nézetünk szerint megfelelően méri a vállalatok termékfejlesztési gyakorlatának színvonalát. Ehhez kiindulópontunkat az előző részben ismertetett cikkek eredményei jelentették. Minden változót 1-5 skálán mértünk, ezek összeadásával hoztuk létre a termékfejlesztési gyakorlat indexét, melynek terjedelme 14 és 70 között van. Az index három dimenziójának kialakítása is a szakirodalomra támaszkodva, elméleti megfontolásokon alapult.

Mivel a versenyképességi kutatási program innovációs része nem kifejezetten a termékfejlesztés vállalati menedzsmentjére koncentrált, ezért nálunk egy-egy kérdés vonatkozik csak olyan tényezôk vizsgálatára, mint a termékfejlesztési funkció kapcsolata a marketinggel, vagy a felsố vezetés szerepe, amelyeket a sikeres termékfejlesztési gyakorlatra vonatkozó kutatások során számos változóval írtak le.

\section{Termékfejlesztési menedzsment:}

- Az innováció kiemelt fontosságú a vállalatnál.

- A dolgozók ismerik a cég termékfejlesztési stratégiáját.

- A felsố vezetés döntő szerepet játszik a termékfejlesztési stratégia kialakításában.

- A felsố vezetés a fejlesztések kudarcát képes tolerálni.

- Érvényesül a fejlesztésben a marketingszemlélet.

- A termékfejlesztést a felsố vezetés támogatása segíti.

- A termékfejlesztést jól múködő ösztönzési rendszer segíti.

- A termékfejlesztést informatika alkalmazása segíti. 
Funkciók közötti együttmúködés:

- A termékfejlesztést segíti a $K+F$ együttmúködése a kereskedelmi és termelóegységekkel.

- A termékfejlesztést jól múködő teamek támogatják.

- Intenzív a kommunikáció a termékfejlesztésben részt vevố osztályok között.

- Termékfejlesztési ötletek belsố vállalati forrásokból.

\section{Külsó kapcsolatok:}

- Együttmúködés vevốkkel, szállítókkal, versenytársakkal.

- Együttmúködés kutatóintézetekkel, egyetemekkel.

A termékfejlesztési gyakorlat és teljesítmény közötti kapcsolat vizsgálata előtt szóráselemzést végeztuink a legjobb gyakorlat méret, ${ }^{2}$ tulajdon és iparághoz tartozás szerinti különbségeinek feltárására. Vállalatméret esetében a nagyvállalatok innovációs gyakorlata a legkiemelkedőbb, igaz, ebben az eredményben valószínúleg az is tükröződik, hogy e cégeknél sokkal jellemzőbb a különböző részlegek megléte, így náluk jöhet egyáltalán szóba az indexben hangsúlyosan szereplő
A termékfejlesztési gyakorlat indexe vállalati jellemzók

(méret, tulajdon, iparági besorolás) szerint

\begin{tabular}{|l|c|}
\hline \multicolumn{1}{|c|}{ Vállalati jellemzók } & $\begin{array}{c}\text { Innovációs } \\
\text { gyakorlati index } \\
\text { átlagos értékei } \\
\text { (14-70 pont) }\end{array}$ \\
\hline Kisvállalat & $42,4 * * *$ \\
Középvállalat & $45,2 * * *$ \\
Nagyvállalat & $48,8^{* * *}$ \\
\hline Többségi állami tulajdonú & $43,1 *$ \\
Többségi belföldi (nem állami) tulajdonú & $45,7 *$ \\
Többségi külföldi tulajdonú & $48,6 *$ \\
\hline Élelmiszer-ipari & $45,6 * *$ \\
Könnyúipari & $43,0^{* *}$ \\
Vegyipari & $50,7 * *$ \\
Gépipari & $45,2 * *$ \\
Egyéb feldolgozóipari & $45,8^{* *}$ \\
Átlag & $\mathbf{4 6 , 1}$ \\
\hline
\end{tabular}

$* \mathrm{p}<0,1 * * \mathrm{p}<0,05 * * * \mathrm{p}<0,01$

2. táblázat

A termékfejlesztési gyakorlat, a termékfejlesztési teljesítmény és az üzleti teljesítmény korrelációs mátrixa

\begin{tabular}{|l|c|c|c|c|c|}
\hline & $\begin{array}{c}\text { Termék-fejlesz- } \\
\text { tési gyakorlat } \\
\text { indexe }\end{array}$ & $\begin{array}{c}\text { Termék-fejlesz- } \\
\text { tési teljesítmény } \\
(\mathbf{1})\end{array}$ & $\begin{array}{c}\text { Termék-fejlesz- } \\
\text { tési teljesítmény } \\
(\mathbf{2})\end{array}$ & $\begin{array}{c}\text { Üzleti } \\
\text { teljesítmény } \\
(\mathbf{1})\end{array}$ & $\begin{array}{c}\text { Üzleti } \\
\text { teljesítmény } \\
(\mathbf{2})\end{array}$ \\
\hline $\begin{array}{l}\text { Termékfejlesztési } \\
\text { gyakorlat indexe }\end{array}$ & - & $0,294^{* * *}$ & 0,076 & $0,213^{* *}$ & $0,238^{* *}$ \\
& $(0,281)^{* *}$ & $(0,069)$ & $(0,179)^{*}$ & $(0,203)^{*}$ \\
\hline $\begin{array}{l}\text { Termékfejlesztési } \\
\text { teljesítmény (1) }\end{array}$ & & - & 0,029 & $0,251^{* * *}$ & $0,212^{* *}$ \\
& & $(0,074)$ & $(0,186)^{*}$ & $(0,080)$ \\
\hline $\begin{array}{l}\text { Termékfejlesztési } \\
\text { teljesítmény (2) }\end{array}$ & & & - & $-0,116$ & 0,102 \\
& & & & $-0,145)$ & $(0,118)$ \\
\hline Üzleti teljesítmény (1) & & & & & $0,594^{* * *}$ \\
\hline Üzleti teljesítmény (2) & & & & & - \\
\hline
\end{tabular}

Zárójelben a parciális korrelációs eredmények. Kontrollváltozók: létszám, külföldi tulajdon aránya, iparághoz tartozás. $* \mathrm{p}<0,1 * * \mathrm{p}<0,05 * * * \mathrm{p}<0,01$

funkciók közötti együttmúködés szerepe. Emellett a kutatóintézetekkel, egyetemekkel történő K+F kooperációk létesítésére is a nagyok rendelkeznek leginkább a megfelelő szakembergárdával és anyagi háttérrel. A többségi külföldi tulajdonú cégek termékfejlesztési gyakorlati indexe a legmagasabb, míg az állami tulajdonúaké a legalacsonyabb. Az igazság kedvéért hozzá kell tennünk, hogy mintánkban a külföldi tulajdonú cégek között csupán egy kisvállalat található. Az iparágak közül a vegyiparban kiemelkedően a legelóremutatóbb a termékfejlesztési menedzsment (1. táblázat).

A termékfejlesztési teljesitményt a 2001 és 2003 között bevezetett új termékeken belül a világon, illetve Magyarországon újnak tekinthetô termékek arányával (termékfejlesztési teljesítmény 1), valamint a 2003-as árbevételben az új vagy jelentôsen megújított termékekból származó bevétel arányával mértük (termékfejlesztési teljesítmény 2). Az üzleti teljesítményt az ipar- 
ági átlaghoz viszonyított árbevétel-arányos nyereség (üzleti teljesítmény 1), valamint a legerósebb versenytárshoz viszonyított jövedelmezôség (üzleti teljesítmény 2) színvonala alapján. Bár ez utóbbiak esetében szubjektív mutatóról van szó, mivel a vállalatvezetốknek kellett értékelniük 1-tól 5-ig vállalatuk pozícióját, mégis a vállalatok jövedelmezőségi adataival összevetve azt mondhatjuk, hogy reálisan tükrözik a valóságos helyzetet.

A 2. táblázatban találhatók a korrelációs, zárójelben pedig a parciális korrelációs számítások eredményei, mely utóbbi számításokhoz a vállalat létszámát, a külföldi tulajdon arányát és az iparági besorolást vontuk be kontrollváltozóként. A táblázatból megállapítható, hogy a termékfejlesztési teljesítmény két mérôszáma között nincs szignifikáns korreláció. Ez vagy azzal magyarázható, hogy az új termékek egyelőre kevés árbevételt generáltak, vagy esetleg azzal, hogy alacsony az arányuk a vállalat termékkínálatában.

A termékfejlesztési gyakorlat indexe a világon és/ vagy Magyarországon elsóként bevezetett termékek (termékfejlesztési teljesítmény 1) arányával pozitív szignifikáns korrelációt mutat, míg a termékfejlesztési teljesítmény másik változójával nincs szignifikáns kapcsolatban. Az új termékek árbevételhez való hozzájárulása (termékfejlesztési teljesítmény 2) nincs kapcsolatban az üzleti teljesítmény mutatóival sem. A termékfejlesztés menedzsmentjében kiváló cégeket magas szintú üzleti teljesítmény is jellemzi. A „Versenyben a világgal 2004-2006" kutatási program egy másik vizsgálatának eredménye szerint a marketing- és a termelési funkció kiválósága szintén hozzájárul az üzleti sikerhez, a logisztika funkció esetében ellenben ezt nem sikerült kimutatni (Demeter - Kolos, 2006).

Mint a zárójelben található értékek jelzik, a termékfejlesztési gyakorlat indexének a világ/hazai új termékek arányával és az üzleti teljesítmény változóival vett parciális korrelációs együtthatóinak értéke valamivel kisebb, ugyanakkor továbbra is szignifikáns. Ezek szerint bár a méret, a tulajdon és az iparági hovatartozás hatással van a változók közötti kapcsolatokra, a korreláció érvényesnek tekinthető (Sajtos - Mitev, 2007).

Ugyanakkor a termékfejlesztési teljesítmény (1) és a legerôsebb versenytárshoz viszonyított jövedelmezôség (üzleti teljesítmény 2) közötti korreláció látszólagosnak bizonyult. A külföldi tulajdon aránya döntő hatással van e korrelációra, ugyanis ezt kihagyva a parciális vizsgálat kontrollváltozói közül az eredmény szignifikáns maradt. A termékfejlesztési teljesítmény (1) és az üzleti teljesítmény (1) mutatójának a korrelációs együtthatója valamivel kisebb, de továbbra is szignifikáns.

\section{Összegzés}

Felmérésünk eredményei szerint elsősorban a nagyvállalatok, a többségi külföldi tulajdonban lévók és a vegyipari cégek termékfejlesztési tevékenysége közelíti a vonatkozó irodalomból leszúrhető legjobb gyakorlatot. Megállapítottuk, hogy a termékfejlesztés megfelelő menedzsmentjére nagy súlyt helyező és a versenypiacaikon újnak számító termékeket bevezető cégek üzletileg is sikeresek. Ugyanakkor, ha a termékfejlesztési teljesítményt az új termékeknek az árbevételhez való hozzájárulásával mértük, már nem találtunk szignifikáns korrelációt sem a termékfejlesztési gyakorlattal, sem az üzleti teljesítménnyel. Ennek ellenére az eredmények összességében abba az irányba mutatnak, hogy érdemes a vállalatoknak a termékinnovációt kiemelten kezelni, mert jelentôsen hozzájárul versenyképességükhöz. A legjobb gyakorlat fóbb jellemzóinek bemutatásával pedig talán ez a cikk is útmutatást adhat a menedzsereknek, hogy mire kellene fokozottabban odafigyelni az új termékek fejlesztése során. Ugyanakkor, mint a korábbiakban is utaltunk rá, nem kifejezetten a cikkben tárgyalt témára irányult az a kutatás, melynek kérdőívére támaszkodhattunk, ezért a jövoóben egy sokkal célzottabb és részletesebb kérdőívvel végzendő felmérésre lenne szükség.

\section{Lábjegyzet}

${ }^{1}$ A cikk a Budapesti Corvinus Egyetem Versenyképesség Kutató Központjának „Versenyben a világgal 2004-2006” címú kutatási programjának anyagi támogatásával készült.

2 A vállalatméret megállapítása a létszám, az árbevétel és az eszközérték adatai alapján történt (Wimmer - Csesznák, 2005).

\section{Felhasznált irodalom}

Cooper, R. G. (1980): Project NewProd: Factors in New Product Success. European Journal of Marketing, Vol. 18., p. 3-54.

Cooper, R. G. (1993): Winning at New Products: Accelarating the Process from Idea to Launch. Reading, MA: Addison-Wesley

Cooper, R. G.- Kleinschmidt, E. (1995): Benchmarking the Firm's Critical Success Factors in New Product Development. Journal of Product Innovation Management, 12 (5), p. 374-391.

Demeter K. - Kolos K. (2006): Marketing, termelés vagy logisztika? Melyik befolyásolja leginkább a vállalati eredményességet? Versenyben a világgal 2004-2006. BCE Versenyképesség Kutató Központ, 31. sz. múhelytanulmány

Kenneth, K. B. - Barczak, G. - Moss, R. (2006): Establishing an NPD best practice framework. Journal of Product Innovation Management, 23 (2), pp. 106-116. 
Lesi M. (2005): A 2004-es versenyképesség-kutatás vállalati mintájának alapjellemzói és reprezentativitása. Versenyben a világgal 2004-2006. BCE Versenyképesség Kutató Központ, 2. sz. múhelytanulmány

Montoya-Weiss, M. - Calantone, R. (1994): Determinants of New Product Performance: A review and meta analysis. Journal of Product Innovation Management, 11 (5), p. 397-417.

Rothwell, R. (1974): SAPPHO Updated: Project SAPPHO

Phase II, Research Policy, Vol. 3., No. 3., p. 192-214.
Sajtos László - Mitev Ariel (2007): SPSS kutatási és adatelemzési kézikönyv. Alinea Kiadó, Budapest

Wimmer Á. - Csesznák A. (2005): Vállalati jellemzók és öszszefüggéseik az EU-csatlakozás idején - a „Versenyben a világgal" kutatási programban részt vevő vállalatok jellemzése. Versenyben a világgal 2004-2006. BCE Versenyképesség Kutató Központ, 3. sz. múhelytanulmány

Zirger, B.J. - Maidique, M.A. (1990): A Model of New Product Development: An empirical test. Management Science Vol. 36., p. 867-883.

\section{A minta alapjellemzôi}

\begin{tabular}{|l|c|c|}
\hline & N & \% \\
\hline Vállalatméret & & 22,1 \\
Kis (10-49 fó) & 24 & 38,5 \\
Közepes (50-249 fó) & 42 & 39,4 \\
Nagy (250 fó felett) & 43 & \\
\hline Tulajdonosok típusa & 16 & 14,7 \\
Többségi állami tulajdonú & 53 & 48,6 \\
Többségi belföldi (nem állami) tulajdonú & 34 & 31,2 \\
Többségi külföldi tulajdonú & 6 & 5,5 \\
Adathiány & 20 & 18,3 \\
\hline Iparág & 21 & 19,3 \\
Elelmiszer-ipari & 23 & 21,1 \\
Könnyúipari & 23 & 21,1 \\
Vegyipari & 22 & 20,2 \\
Gépipari & $\mathbf{1 0 9}$ & $\mathbf{1 0 0}$ \\
Egyéb feldolgozóipari & & \\
\hline Összesen & & \\
\hline
\end{tabular}

2. Az alkalmazott változók legfontosabb statisztikai jellemzői

\begin{tabular}{|lc|c|c|c|}
\hline \multicolumn{2}{|c|}{ Változó } & Átlag & Standard eltérés & Esetszám \\
\hline Termékfejlesztési gyakorlat indexe (14-70) & 46,08 & 8,38 & 99 \\
\hline Termékfejlesztési teljesítmény 1 & $(\%)$ & 25,61 & 35,07 & 109 \\
\hline Termékfejlesztési teljesítmény 2 & $(\%)$ & 21,48 & 28,55 & 103 \\
\hline Üzleti teljesítmény 1 & 3,09 & 1,06 & 106 \\
\hline Üzleti teljesítmény 2 & 2,93 & 1,04 & 99 \\
\hline
\end{tabular}

Cikk beérkezett: 2008. 1. hó

Lektori vélemény alapján átdolgozva: 2008. 3. hó 